\title{
INTERNATIONAL FINANCIAL SUPPORT FOR PUBLIC TRANSPORT AT THE REGIONAL LEVEL
}

\author{
Nataliia Vyhovska ${ }^{1}$, Olena Vyhovska ${ }^{2}$
}

\begin{abstract}
The purpose of the article is to assess the practice of attracting international sources of financial support for public transportation at the regional level, to identify problems with insufficient effectiveness of the implementation of international financial support projects and the formation of solutions at various system levels. It is determined that the main sources of financing of transport entities are self-financing, lending, state and international financial support. The preconditions for the use of credit funds of international financial donors for financing public transport and the conditions for lending to transport entities are described. Peculiarities of public transport lending by way of implementation of the project "Ukraine Urban Public Transport" are analyzed, and it is highlighted that its purpose is to realize the strategic priorities of the transport industry, institutional reforms and informatization. It is clarified that the responsibility for the performance gaps under the project, defined in the assistance agreements, is allocated to the City Councils and / or public transport entities.

An assessment of international financial support is made and the reasons for short receipt of funds by transport companies from international financial organizations are specified. The amount of losses on incomplete implementation of the plan of expenditures and provision of credits for the realization of projects in the transport sector of Ukraine is clarified. Inefficiency in finding additional sources of financing of the project "Ukraine Urban Public Transport" is justified due to the impossibility to allocate financial responsibility to a certain project group in case of delay in non-implementation of the project plan at all levels. The organizational and financial mechanism of providing international financing for urban public transport by the European Investment Bank is proposed. It is argued that the mentioned mechanism, in contrast to the existing ones, identifies control points for the flow of financial resources, which provides an opportunity to suggest ways to intensify control activities by observers of the European Investment Bank and the public. The main disadvantage of receiving financing from the European Investment Bank in the framework of the project "Ukraine Urban Public Transport" is identified: obligations to pay VAT to the State budget are allocated to the business entity of the transport sector. The problems of inefficiency of implementation of financing sources of international financial organizations (on the example of the European Investment Bank) are identified and the directions of their solution are offered. The need for coordination of bodies of state supervision at the regional level with the observers' control activity is identified to promote the efficient and meaningful use of international financial sources by economic entities in the transport sector. It is proposed to supplement the state and supranational control with public control functions through the following options for establishing cooperation: 1) interaction of public councils at local self-government bodies with independent observers of international organizations involving auditors of the Accounting Chamber; 2 ) control of the process of implementation of the credit project of important infrastructure projects, including public transportation, by public organizations of the regional level.

Methodology. In accordance with the purpose, the following research methods were used: a systemic approach (in identifying the components of the organizational and financial mechanism of international financial projects and their relationship), methods of comparative and statistical analysis (in assessing the receipt of financial resources from international financial sources). Results. The problems of inefficiency of implementation of financing sources of international financial organizations (on the example of the European Investment Bank) are identified and the directions of their solution are offered. Practical implications. Improving efficiency of using the international sources
\end{abstract}

\footnotetext{
Corresponding author:

${ }^{1}$ Zhytomyr Polytechnic State University, Ukraine.

E-mail: vygng@ukr.net

ORCID: https://orcid.org/0000-0001-7129-6169

ResearcherID: B-2434-2018

${ }^{2}$ Zhytomyr Polytechnic State University, Ukraine.

E-mail: alenavygovska@gmail.com

ORCID: https://orcid.org/0000-0002-7905-0494
} 
of financial support at the regional level will contribute to the renewal of the rolling stock of urban public transport, ensure its sustainable operation and development, save jobs at utility enterprises, increase revenues of utility enterprises from the provision of transportation services to the population. Value/originality. The organizational and financial mechanism for providing international financial support for urban public transport by the EIB has been developed, which, unlike the existing ones, identifies control points for grant flows, providing an opportunity to suggest ways to intensify control activities by the EIB observers and the public.

Key words: organizational and financial mechanism for providing international financial support, international financial sources, financial support, transport sector.

JEL Classification: L90, F30

\section{Introduction}

The main challenge for the implementation of state-building changes in the transport sector at the regional level is the low financial capacity of local budgets and the complicated regulatory mechanism for obtaining financial support from international financial institutions.

The main sources of financing for transport companies are self-financing, lending, government and international financial support. According to statistics in 2019, 584.45 billion UAH of capital investments was attracted to the economy of Ukraine, 11\% higher than in 2018. Accordingly, capital investments in transport, warehousing, postal and courier activities amounted to 41.37 billion UAH, 7.9\% less than in the previous year. In general, investments in the transport sector from all the above sources of financing have reached only $2 \%$ of GDP in Ukraine, while in the EU - 3\% (average for 27 countries), and budget financing in Ukraine is at $0.33 \%$ of GDP, in the EU - $1.1 \%$ (Nikiforuk, Chmyryova, \& Fedyai, 2015). These statistics show a permanent short financing of the transport sector, which requires the involvement of international financial organizations to finance infrastructure transport projects.

Prerequisites for the use of credit funds of international financial organizations to finance public transport are the following: lack of budget funds and the complexity of the mechanism of state support; imperfect mechanism for financing regional development programs; limited access to state guarantees for the implementation of PPP projects at the regional level; insufficient state funding to improve communal infrastructure.

The issues of low level of use of provided credit funds by international financial institutions for the development of various infrastructure projects, including public transportation at the regional level, inertia of participants in investment projects at the state level, remain unresolved.

\section{International financial donors}

It is quite common practice for local authorities to raise loans from international financial institutions to finance the development of the transport sector. Debt obligations are assumed by local governments on traditional credit terms (maturity, payment and repayment). The European Bank for Reconstruction and Development (EBRD) and the European Investment Bank (EIB) are international donors of financial support for transport entities in the public and private sectors. The source of financing for the development of the transport sector is grant funds provided to finance the development of enterprises in the transport sector (international technical assistance, grants from international donor organizations).

The European Bank for Reconstruction and Development is the largest donor of public and private sector lending in developing countries and the main international investor in Ukraine's transport sector. Loans are provided for a period of 12-15 years with a commission for liabilities of $0.5 \%$ per annum, a one-time fee of $1 \%$ of the loan amount, a floating rate tied to the average rate of the interbank market of the EU (Euribor) + 1\% annual rate (Kolosova, 2015). In particular, within the project "Ukraine Urban Public Transport: Modernization of Trolleybus Transport in Zhytomyr", which is implementing with the grant support of the European Bank for Reconstruction and Development with the involvement of an independent international consultant - French company EGIS Internationale and its regional office EGIS Ukraina, on October 15,2020, the bids of the bidders were revealed on the EBRD Electronic Procurement Platform (ECEPP) to determine the contractor for the construction of a new trolleybus line.

The European Investment Bank is another subject of financing the development of urban public transport in 11 cities of Ukraine. In 2016, Ukraine and the European Investment Bank signed a Financial Agreement to provide a loan of 
200 million EUR to support the project "Ukraine Urban Public Transport", which came into force on May 11, 2017. The loan is aimed at upgrading rolling stock, reconstruction and expansion of transport infrastructure of Ukraine. The initiator of the project "Ukraine Urban Public Transport" is the Ministry of Infrastructure of Ukraine, the borrowers are the Ministry of Finance and the Ministry of Infrastructure, through which credit funds are provided to final recipients under loan transfer agreements.

Within the project "Ukraine Urban Public Transport" financial support planning for subprojects is obliged to guarantee the financial sustainability of investments taking into account existing and future adjusted tariffs, co-financing conditions and other grant support to fill the gap of funds. It is determined that such conditions require the search for additional sources of funding from international financial organizations, institutions and donors. The search for additional sources of financial support for the project is entrusted to the Ministry of Infrastructure of Ukraine, the Ministry of Finance of Ukraine and city councils and / or business entities or passenger transport companies. In our opinion, this method of finding alternative participants in project cofinancing is ineffective because the responsibility is scattered, it is impossible to allocate financial responsibility to one of the project groups in case of delay in finding a donor and failure to implement the project plan at the state and regional levels.

Lending from the European Investment Bank can provide up to $100 \%$ of the financial security of the total cost of the subproject and up to $50 \%$ of the total investment of the project "Ukraine Urban Public Transport". According to the project, the supervision functions are entrusted to the Ministry of Infrastructure of Ukraine and the Ministry of Finance of Ukraine. The project financing should be supervised once every six months; the process includes the determination of the relevant share of the European Investment Bank loans.

In connection with the signing of the Law of Ukraine "On Ratification of the Financial Agreement (Project "Ukraine Urban Public Transport") between Ukraine and the European Investment Bank" No. 2009-VIII dated April 12, 2017, the strategic goals and objectives of the Ministry of Infrastructure are aimed at developing urban passenger transport in the cities of Ukraine. Indicators of the total amount of credit funds of the European Investment Bank in 2018 $6,152,000.0$ thousand UAH, in 2019 this amount increased by $76,000.0$ thousand UAH and reached $6,282,000.0$ thousand $\mathrm{UAH}$, and in 2020 $5,200,000.0$ thousand UAH. The data show that the budget program of the Ministry of Infrastructure of Ukraine in 2017 is aimed at implementing measures to support the implementation of Ukraine's transport strategy. The amount of budget expenditures/budget allocations in 2017 amounted to $722,150.0$ thousand UAH.

According to the statistics of the Accounting Chamber in 2017, the selection of funds for the implementation of projects for the development of urban passenger transport in the cities of Ukraine was not carried out in full. The reasons for short receipt of funds from international financial organizations are the conclusion by the group of the implementation of subprojects of sub-loan agreements at the end of the year; improper organization of the competition with the selection of objects; delays in the preparation and approval of estimates and other documentation between the working groups of projects.

In the period from 2017 to 2019 , due to the low and / or missing tranche disbursement from the EIB, Ukraine would have to pay 142,252 EUR as a commission for reserving funds, which was $0.5 \%$ per annum and was accrued on the unselected and reserved part of the loan. It should be noted that the responsibility for the failure to achieve the performance indicators set out in the assistance agreements is allocated to the city councils and / or passenger transport entities. The consequence of the unprofessionalism of the local self-government is the reduction of tranches from international donors. Accordingly, in 2018 there was a low tranche disbursement for the implementation of investment projects through loans raised by the state from foreign countries, banks and international financial organizations due to the lack of proper organization, and therefore the plan of expenditures and lending for transport projects is not fulfilled. As of the beginning of 2018, the balance of funds from international organizations for the support and implementation of Ukraine's transport strategy amounted to 35.3 million UAH, or $4.7 \%$ of the plan. At the expense of credit funds in 2018, expenditures and crediting for the development of urban passenger transport in the cities of Ukraine in the amount of 125.0 million UAH were not started.

\section{Discussion}

A retrospective analysis of the subproject implementation mechanism reflects the following reasons for the failure of the implementation of 
tranches from the European Investment Bank and the European Bank for Reconstruction and Development: low level of qualification of specialists who implement projects and subprojects of international financial institutions; non-compliance with the requirements of tender procurement of rolling stock according to official agreements between the state and international financial organizations; delays in drawing up official documentary procedures by the local self-government due to corrupt approaches to work with potential beneficiaries; irresponsible attitude of officials to make timely decisions for the timely implementation of investment projects and subprojects.

The organizational and financial mechanism for providing international financial support for urban public transport by the EIB is presented in Figure 1. It is argued that the mentioned mechanism, in contrast to the existing ones, identifies control points for the flow of financial resources, which provides an opportunity to suggest ways to intensify control activities by observers of the European Investment Bank and the public.

Consequences of delays in obtaining international financial support from the European Bank for Reconstruction and Development and the European Investment Bank are: damage caused to the state budget due to low and / or no disbursement in the form of a commission for reservation of funds, which is $0.5 \%$ per annum and is accrued on the unselected and reserved part of the loan; non-receipt by the state budget of $10 \%$ of the tranche for state guarantees; underpayment by the state budget of $20 \%$ of the tranche for VAT; slowing down the implementation of the "Transport Strategy 2030" at the state and regional levels; postponement of renewal of rolling stock of all types of public transport of Ukraine.

It is determined that the main disadvantage of receiving financial support from the European Investment Bank under the project "Ukraine Urban Public Transport" is the obligations on the independent payment of VAT to the state budget allocated to the transport entity. Such companies will not be able to receive a VAT refund after the purchase of rolling stock, because they do not pay this tax on the sale of one-time tickets. The consequence of this factor is the benefit from the implementation of investment agreements for the state and the coercive nature of obtaining funds from an international donor of local authorities, as local budgets are unable to implement rapid changes in the transport sector at the regional level.
Priority tasks of Ukraine in cooperation with the European Bank for Reconstruction and Development and the European Investment Bank: to improve the management system at all stages of project implementation through specialized selection of highly qualified managers to project groups; to reduce terms of project implementation between all its stages - from signing of the agreement to realization; to increase the sample of investments under the project from the EBRD and / or the EIB by simplifying tender procedures as soon as possible; to increase the number of projects financed by international financial institutions in the national currency; to conduct an overall assessment of the project implementation in terms of their compliance with current legislation and the "Transport Strategy 2030"; introduction of monitoring and control over the project implementation at all its stages at the regional level; at the legislative level, to provide for the strengthening of responsibility for the timeliness of decision-making by officials at various stages of management.

Based on the above, the identification of problems of inefficiency in the implementation of sources of financing of international financial organizations (on the example of the European Investment Bank) and the proposed areas for their solution are presented in Table 1.

An important problem in attracting international financial sources is the mismatch between the level of the problem that arises and the level of its solution. In particular, the fact that the subject of guaranteeing the repayment of the loan at the regional level are city councils and / or transport organizations owned by the city community. On the one hand, in the context of decentralization, the concentration of financial obligations at the regional level will allow for ongoing monitoring and control of the subproject, on the other hand, the Accounting Chamber has control over the use of international funds under Art. 7 of the Law "On the Accounting Chamber of Ukraine": "use of credits (loans) attracted by the state to the special fund of the state budget from foreign states, banks and international financial organizations, implementation of international agreements of Ukraine, which leads to financial consequences for the state budget, within the limits related to such consequences "(Law of Ukraine "On the Accounting Chamber", 2015). In addition, the use of funds is monitored by independent observers from the European Investment Bank in accordance with the terms of the loan agreement. 


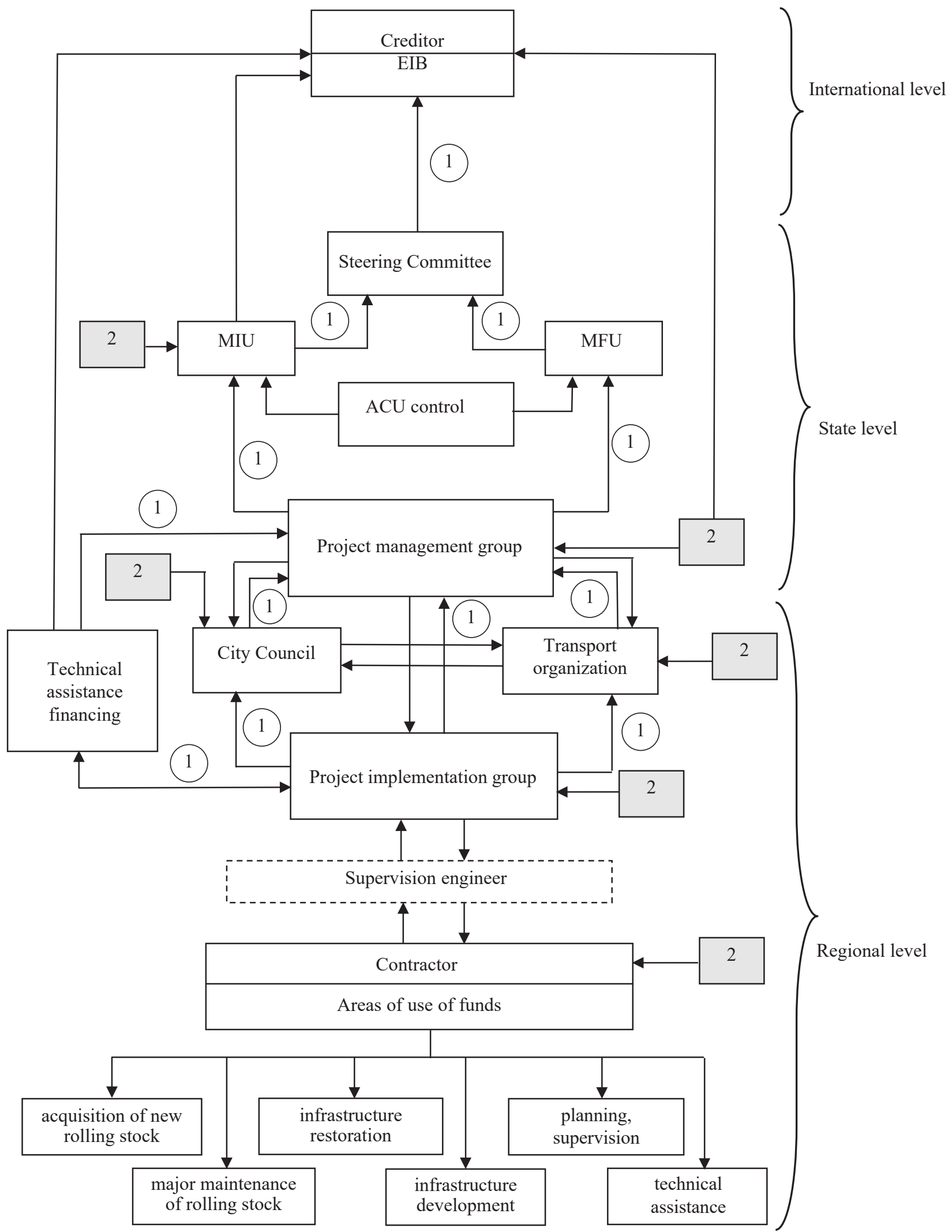

Explanation to Figure 1: 1 - reporting on the results of project management (implementation); 2 - control by the EIB observers

Figure 1. Organizational and financial mechanism for the provision

of international financial support for urban public transport by the EIB

Source: development of authors (Infrastructure projects of the Ministry of Infrastructure of Ukraine, 2017) 


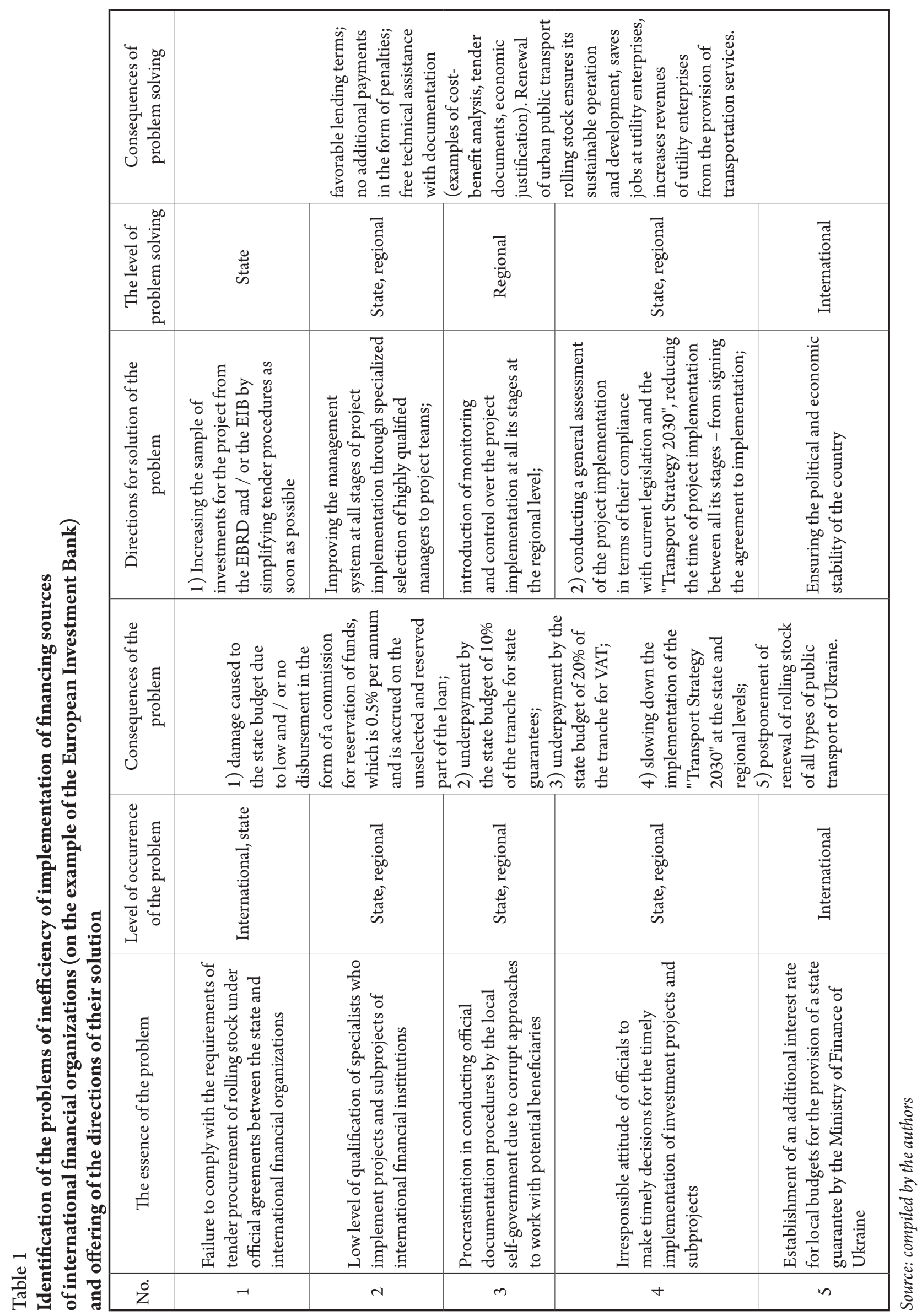


At the same time, it is necessary to coordinate the controlling bodies of the state at the regional level with the control activities of the above-mentioned observers, which will contribute to the effective and meaningful use of international financial sources. Given the social component of public transport and the importance of infrastructure projects of this level for society, we propose to supplement state and supranational control with public control functions. Options for establishing such cooperation may be as follows: 1) interaction of public councils at local self-governments with independent observers of international organizations with the involvement of auditors of the Accounting Chamber; 2) control by public organizations of the regional level of the process of implementation of the credit project of important infrastructure projects, which include transportation by public transport.

The first option involves the development of a plan for coordination of control actions with the definition of the responsibilities of each member of the control group; The second option provides for the possibility for a public organization to have access to financial documents for the implementation of a loan project by the EIB observers, which determines the need to form qualification criteria for selecting such an organization and involving its individual members in the control process. The first option of cooperation seems more realistic to us, as the implementation of the second option is associated with the need for a high level of trust in public organizations operating in modern Ukraine. For the full implementation of the second option of public control, it is necessary to form a civil society, the foundations of which are just emerging.

\section{Conclusions}

It is determined that the cooperation of international financial organizations with local governments and / or public transport entities of Ukraine will contribute to the renewal of the rolling stock of urban public transport; ensure its sustainable operation and development; will save jobs at utilities; increase revenues of utilities from the provision of transportation services to the population.

The reasons for non-receipt of funds by transport enterprises from international financial organizations are clarified. An assessment of international financial suport is made and the amount of losses on incomplete implementation of the plan of expenditures and provision of credits for the realization of the projects in the transport sector of Ukraine is clarified.

The organizational and financial mechanism for providing international financial support for urban public transport by the European Investment Bank is developed, which identifies control points for grant flows, which allows to suggest ways to intensify control activities by observers of the European Investment Bank and the public.

The identification of problems of inefficiency of introduction of sources of financing of the international financial organizations on an example of the European investment bank is offered as well as the directions of their solutions.

The need for coordination of bodies of state supervision at the regional level with the observers' control activity is justified to promote the efficient and meaningful use of international financial sources by economic entities in the transport sector.

\section{References:}

European PPP Market: 49 deals (2015). European Investment Bank. Available at: http://www.eib.org/ epec/ (in Ukrainian)

Chamber of Accounts (2020). Conclusions about the results of the analysis of the annual report on enforcement of the Law of Ukraine «On the state budget of Ukraine for 2020». Available at: https://rp.gov.ua (in Ukrainian)

Kolosova, V. P. (2015). State budget expenditures planning for implementation of investment programs credited by international organizations. Finance of Ukraine, vol. 2, pp. 27-38. (in Ukrainian)

Law of Ukraine on the ratification of the Financial Agreement between Ukraine and the European Investment Bank № 2009-VIII (2017, April 12). Vidomosti Verckhovnoi Rady Ukrayiny. (in Ukrainian)

Law of Ukraine on the accounting chamber № 576-VIII (2015, July 2). Vidomosti Verckhovnoi Rady Ukrayiny. (in Ukrainian)

Nikiforuk, O. I., Chmyryova, L. Yu., \& Fedyai, N. O. (2015). Prospects for financing transport projects under international financial assistance. Ukraine economy, vol. 4, pp. 45-57. (in Ukrainian)

Povna, S. V., Sikach, N. M., \& Ignetenkov, O. L. (2018). Public management of modernization in the city's public transport system. Public administration: research and development, vol. 1, pp. 39-52. (in Ukrainian) 